\title{
Model Innovation and Scheme of Music Online Open Course
}

\author{
Yefei Yan \\ Zhao Tong University, Yunnan, China, 657000
}

Keywords: Music online course; Education teaching reform; Mode innovation

\begin{abstract}
With the opening of "listening to music" course by Yale University to the whole world in 2009, China has also initiated the relevant reform of music course standard. In November 2017, "music online open course construction and education teaching reform seminar for colleges and universities" was successfully held in capital normal university. This meeting is aimed at music online open course construction and education teaching reform and other core issues to exchange and discuss, which indicates that music online open courses in China will become one of the main directions in the future. This paper is mainly divided into three aspects. First, analyzing the demand of music online education. Second, thinking about the construction of online courses. Third, studying the reform of education teaching. This paper is expected to help students learn to explore, create, cooperate and share music, so as to improve their learning ability.
\end{abstract}

\section{Introduction}

Statistics is a highly comprehensive subject, which widely exists in society production and daily life. Making good use of statistics will make our life more convenient. Reviewing the development process of statistics, it has been made continuous progress in actual life and application. With the rise of the era of big data, traditional statistics are also making new changes. The era of big data has injected fresh blood into traditional statistics, changed the inherent mode of thinking, and also brought a lot of challenges. Therefore, how to deal with this challenge and change traditional statistics should be given due attention.

At the end of the 20th century, online education started slowly in China, and Internet information technology and education teaching achieved a deeper interactive integration. In 2012, the development of three major MOOC platforms in the United States set off a global wave of online education. At the same time, it triggered the reform and development of online education. For example, in foreign open courses, 'listening to music' of Yale university is an innovative music appreciation course in the history of music in the west. Video public courses is also a typical course in Chinese universities. Such as 'music aesthetic basic issues' of central music college,' a survey of western music history ', 'traditional Chinese instrumental music'. These three courses are offered by the top experts in related fields in China, and they are excellent entry courses of music aesthetics, western music history and traditional instrumental music. South China university of technology offers "entering the world of symphonic music", which enables students to get the enlightenment and edification of music from the perspective of history, theory and appreciation. These courses and 
lectures are not only free to browse and download through the computer, but also better meet the living habits of modern people. Students can browse anytime and anywhere on mobile devices such as mobile phones through the client. "Amoy course" has become a fashion in students' learning, which has also become a new way for college teachers to rapidly improve and develop themselves. Open course was launched at MIT in 2001.In 2011, the course realized video and began to operate under the intervention, localization, collection, classification and branding of large portal websites. All of these measures eventually caused great repercussions among the general population. This phenomenon provides a practical precedent for the globalization, popularization and lifelong development of education. It is of great significance to promote the construction and application of music online open courses in Chinese universities.

\section{The demand of music online education era}

\subsection{Direction and guidance of network informatization}

At present, China has transferred from the past chalk blackboard teaching era to big data, Internet + education informatization. Wu bo conducted data statistics on online education construction in recent 4 years, pointing out that there are more than 3,260 online courses in colleges and universities, 430 colleges and universities involved in online construction and 600 colleges and universities involved in application. At present, more than 6.5 million students have obtained credits through online courses, and there are more than 10 well-known courses platforms. These data prove that online education is gradually being promoted and popularized. However, information technology makes this feature fully reflected, which plays a guiding role in music online education and also poses new challenges to education online in China. We should establish an online music course alliance facing the direction of network informatization, so that music online education can gradually transform from a single course construction to a series of courses.

\subsection{Resource sharing combining art and science}

With the development of music subject and students' comprehensive quality, single subject education can no longer meet the needs of The Times. The integration of art and science has greatly promoted the online music education process. Online music development course can change the unbalanced status quo of education development between urban and rural areas and realize resource sharing in the education sector. Resource sharing is an inevitable trend of development and also an opportunity for music online education. Relying on the increasingly perfect Internet environment, the construction of music online course learning is an inevitable trend. Realizing the integration of music online course art and local class will play an unprecedented role in the resource construction of music course.

\section{Thinking about the construction of online courses}

\subsection{Online course design}

In the process of online course design, the training objectives, training specifications and course system of online courses should be planned in accordance with the 'national standards for teaching quality of music and dance majors in universities'. The school should establish MOOC/SPOC courses, $\mathrm{O} 2 \mathrm{O}$ teaching and practice modes, which will transform the single-core course design such as general education, basic courses and core courses into a series of course groups. At the same time, the course content design and platform conditions should be adapted to each other, so that we can 
use the online platform to spread the intuitive, interactive, in-depth and effective Chinese music culture to the world.

\subsection{Online course mode}

Online education is a trend of education development in the future, and 'double-division system' will become the mainstream of education in the future.'dual teacher system' means that teachers should be able to control both offline classes and online classes. O2O is Online To Offline."Double teacher system" is a teaching mode based on $\mathrm{O} 2 \mathrm{O}$ teaching applied in online courses, and it is also an important means to improve teaching efficiency. The "double teacher" music education, which builds the $\mathrm{O} 2 \mathrm{O}$ model, is mainly provided by online teachers for online courses and used by offline teachers. Online activities mainly include communication, comments and interaction with online teachers. Offline activities include "flipped classroom", "classroom explanation", "practice and practice" and other practical performances. In the face of the characteristics of music discipline, what online music education needs is exactly this teaching mode integrating online and offline.

\section{Explore the development of music online open courses}

\subsection{Collect resources and advocate research-based teaching}

In the new era, college teachers should keep up with the trend and grasp the latest education resources timely through tracking and searching high-quality education resources. According to their own teaching needs, teachers should collect, sort, classify and apply, effectively broaden their horizons. At the same time, they should localise music open course. Facing with the constantly emerging rich education resources, teachers should select different resources and combine them with the reality of classroom teaching, and then optimize the combination of teaching content. Which promotes the development of teaching ability and the improvement of teaching effect. In order to guide students' research-based learning, teachers must have the ability to collect high-quality education resources before students. At the same time, teachers can constantly adjust and improve their own teaching according to the new education resources and education frontier, and deeply think about the way and direction of their own teaching dynamic development. Which provides music online open course exactly such a platform and support.

\subsection{Carry out modularity and innovation education}

Music online open curriculum makes college teachers face the favorable situation of coexistence of multiple resources. Teachers should reserve and absorb valuable resources and form knowledge modules in their daily study, browsing and lesson preparation. Teachers ensure the flexibility and integrity of teaching in the form of modules according to the actual curriculum requirements. For example, in the teaching of 'music education overview', teachers can establish modules such as "music education principle", "music education concept", "education method", "education teaching practice" and so on. In teaching, teachers advocate that students should further explore and supplement the module resources that teachers have mastered. Teachers need to consciously improve the education content optimization and integration ability. At the same time, teachers can further promote the improvement of the overall teaching ability.Modularized education can break the shackle of the original textbooks, which are only an organic part of modularized education resources. Teachers can ensure the success of classroom teaching by obtaining the support of multiple resources. 


\subsection{Promote sustainable development of teaching}

From the perspective of education quality, whether teachers' teaching effectiveness can be continuously improved is an important condition for education quality. While paying attention to the rules of students' learning, we should also pay more attention to the rules and characteristics of teachers' teaching. Which is of great help to continuously improve the teaching performance of teachers. The improvement of teaching quality depends on teachers' adequate preparation, proper methods, good reflection and continuous improvement in the teaching process. Music online open courses will provide technical and practical support for the comprehensive improvement of teachers' teaching. Which will promote teacher development and teaching progress into a virtuous circle.

\section{Conclusions}

Different music education platforms should be based on their respective education objects and education targets. Therefore, we should make the appropriate education plan and scheme according to the needs, and design the appropriate teaching content and method. The construction of music online open courses in Chinese universities will provide valuable theoretical support and practical thinking for the teaching reform.

\section{References}

[1] Wang youfu. Development trend of online open courses in China from "no. 3 document" [J]. Chinese university teaching, 2015,(07).

[2] Zhang yupeng, zhao hanqiang, li yahan. Analysis on the construction status and countermeasures of online open courses in colleges and universities [J]. China electronic education, 2015,(02).

[3] You jingbo. History and style of popular music [M]. Changsha: hunan literature and art publishing house,2007.

[4] Fan lei.. Thoughts on popular music education in ordinary universities [J]. Music creation, 2010,(01). 